\title{
Genotypes of the hepatitis B virus within the area of Terni, Italy: our experience
}

\author{
Michela Piermarini, Maria Chiara Medori, Alessandra Pagnani, Monica Proietti, \\ Augusto Scaccetti \\ Immuno-haematology and Blood Transfusion Centre, Santa Maria Hospital, Terni, Italy
}

\section{Summary}

Background and aims: The presence of hepatitis B varies depending on the different areas of the world; 10 genotypes of hepatitis $B$ virus (HBV) (A to J) have been identified, and they differ from one another in the nucleotide sequence and geographical location. The various genotypes are associated with a different evolution of the disease and with distinct responses to treatment.

Materials and Methods: From January 2010 to March 2014 we assessed the genotype of the HBV virus on 35 specimens with HBVDNA $>1000 \mathrm{IU} / \mathrm{mL}$. The HBV genotype has been determined through sequencing.

Results: The 35 specimens belonged to individuals with a mean and median age of 42.8 and 40 years respectively: 17 of them were Italian and 18 from other countries. In total there were 19 males: 12 Italians and 7 foreigners. Females were 16: 5 Italians and 11 foreigners. The subjects with $\mathrm{HBV}-\mathrm{DNA} \geq 10^{6} \mathrm{IU} / \mathrm{mL}$ were prevailing, followed by subjects with HBV-DNA between $1000 \mathrm{IU} / \mathrm{mL}$ and $10.000 \mathrm{IU} / \mathrm{mL}$. Out of 35 patients analysed by genotype, we found 20 genotypes $\mathrm{D}$ and 15 non-D genotypes.

Correspondence: Monica Proietti, Immuno-haematology and Blood Transfusion Centre, Santa Maria Hospital, Via Tristano di Joannuccio 1, 05100 Terni, Italy.

Tel.: +39.0744.205529 - Fax: +39.0744.205846.

E-mail:monicaproietti@aruba.it

Key words: Hepatitis B; Immigration; Population dynamics; Viremia; DNA sequencing.

Contributions: MP, MCM, study conception and design; MCM, AP, MP, MPr, laboratory work, collection of data, data analysis, manuscript preparation and final approval of the version to be published.

Conflict of interest: the authors declare no potential conflict of interest.

Received for publication: 5 April 2016.

Revision received: 12 May 2016.

Accepted for publication: 26 May 2016.

CCOpyright M. Piermarini et al., 2016

Licensee PAGEPress, Italy

Microbiologia Medica 2016; 31:5914

doi:10.4081/mm.2016.5914

This article is distributed under the terms of the Creative Commons Attribution Noncommercial License (by-nc 4.0) which permits any noncommercial use, distribution, and reproduction in any medium, provided the original author(s) and source are credited.
Conclusions: The analyses carried out on results suggest that Italy, land of immigration, has become a multi-ethnic country with people coming from high and medium endemic disease areas in terms of HBV. Most patients show D genotype, however the migratory flows lead to the introduction of patients with non-D HBV genotypes in the native population as highlighted in Terni.

\section{Introduction}

The presence of hepatitis B varies in the different areas of the World (12). The hepatitis B virus (HBV) is very widespread also due to its resistance in the environment, with a higher prevalence in China and in Southern Asia and a lower presence in North America and Western Europe: it shows a higher percentage of infection in Central Europe $(10,11)$. Ten genotypes of HBV (named with letters from A to J) have been identified $(19,22)$. The 10 genotypes differ from one another in the nucleotide sequence and geographical location (15). Genotype A is widespread in America, North-West Europe and Africa; genotypes B and $\mathrm{C}$ prevail in China and Japan, while genotype D is found in Southern Europe, Middle East and India (18). Genotype E is found in Africa, in the sub-Saharan region, genotype $\mathrm{F}$ in Central and South America, genotype $\mathbf{G}$ in Eastern and Western Europe and genotype $\mathrm{H}$, a variant of genotype $\mathrm{F}$, from which it has probably broken up within the New World, in Central and South America (2,12,18,21). Genotype I has recently been reported in Vietnam and Laos and genotype $\mathrm{J}$ has been identified in the Ryukyu Islands in Japan, from an old Japanese patient with hepatocellular carcinoma $(1,21,23,24)$. The various genotypes are associated with a different evolution of the disease and with distinct responses to treatment $(18,22)$. The aim of this work is to assess the genotype of the $\mathrm{HBV}$ virus in specimens taken from patients with HBV-DNA $>1000 \mathrm{IU} / \mathrm{mL}$, at the Immuno-haematology and Blood Transfusion Centre (S.I.T.) of the Santa Maria Hospital in Terni, considering their regions of origin.

\section{Materials and Methods}

From January 2010 to March 2014 we assessed the genotype of the $\mathrm{HBV}$ virus on 35 specimens belonging to the same number of patients with HBV-DNA>1000 IU/mL $(8,16)$. These patients were recruited first to satisfy the rare demands of the clinical, as the HBV genotype is required only in exceptional cases and then based on the availability of the ordered kit during that period.

We considered the samples from Italian and foreign patients with HBV-DNA $>1000 \mathrm{IU} / \mathrm{mL}$ present in our laboratory, in order to acquire information and expertise in relation to different geographical origin. 
The assessment of the HBV-DNA was performed on plasma, obtained through the centrifugation (3000 rpm for 20 minutes) of whole blood, taken and transferred into sterile test tubes containing ethylenediaminetetraacetic acid (5). The quantification of HBV-DNA in specimens was carried out through COBAS AmpliPrep/COBAS TaqMan HBV v2.0 Roche test, which enables the automated extraction and amplification with subsequent detection of the virus nucleic acid (measuring range between 20 and $1.7 \mathrm{E}+08 \mathrm{IU} / \mathrm{mL}$ ) (5). The HBV genotype was assessed through sequencing. Each specimen was subjected to a manual extraction of the virus (QIAamp DNA Blood Mini Kit, QIAGEN, Venlo, Netherlands) followed by polymerase chain reaction amplification (TRUGENE HBV Genotyping kit; Siemens Medical Solutions Diagnostics, NY, USA), of the central region of the surface antigen gene (s101-s237) and overlapped region encoding the viral reverse transcriptase gene (rt99-rt280) $(1,3)$.

The amplicons obtained have been used to prepare the CLIPTM, (trademark of Siemens Healthcare Diagnostics) reaction of sequencing. The DNA specimen to be sequenced has been divided into four CLIP $^{\mathrm{TM}}$ sequencing reaction tubes, each one of them contained the DNA polymerase, fluorescent DNA primers to produce bidirectional sequences and all 4 deoxyribonucleotides (dATP, dCTP, dGTP, dTTP). To each one of these reactions we have added just one of the four dideoxy nucleotides (ddATP, ddCTP, ddGTP, ddTTP).

Once concluded the programme in the thermocycler, the DNA was denatured. The sequences obtained have been compared to reference sequences to determine the HBV genotype and the mutations of the analysed specimen (3). Each library contained 7 sequences, one for each HBV genotype (A, B, C, D, E, F and G) (20). The origin of the studied subjects had been obtained through an epidemiological sheet used for virological researches that we carried out, or through the taxpayer's code number appearing on the requests coming with the individual specimens.

\section{Results}

The 35 examined specimens for the genotype of $\mathrm{HBV}$, belonged to as many subjects, with a mean and median age of 42.8 and 40 years respectively: 17 (48.6\%) Italians and 18 (51.4\%) foreigners. All together there were 19 males: 12 Italians and 7 foreigners. Females were 16: 5 Italians and 11 foreigners (Table 1). It is evident the prevalence of Italian males and foreign females. The analysed subjects have been divided into four groups, identified by analysing the levels of HBV-DNA found in specimens. The subjects with HBV-DNA $\geq 10^{6} \mathrm{IU} / \mathrm{mL}$ prevailed: 13 subjects of which 7 Italian males, followed by 11 subjects with HBVDNA between $1000 \mathrm{IU} / \mathrm{mL}$ and $10.000 \mathrm{IU} / \mathrm{mL}$, among which 7 foreign females prevailed (Table 2).

In the 35 patients analysed by genotype we found 20 genotypes $\mathrm{D}$ (57.2\% of total) and 15 non-D genotypes ( $42.8 \%$ of total). Among the non-D genotypes, the genotype with the largest recurrence was genotype A ( $n=7)$, followed by genotype $C(n=3)$ and $F(n=3)$ and by genotype $B(n=2)$ (Table 3$)$. Genotype $B$ has been found in 2 female patients coming from China and Philippines respectively; genotype $\mathrm{C}$ in an Italian patient, in a Bangladeshi patient and in a Thai female patient; genotype $\mathrm{F}$ which is usual in Central and South America has been found in 3 Italian patients. Of the 3 Italian patients with genotype $F$, one reported a long stay in South America where the infection had been contracted; the second patient showed a co-infection with HIV, and reported he regularly visited Colombia. We could not trace the origin and place of infection of the third Italian patient with genotype $F$ and of the two Italian patients with genotype A. Genotype $\mathrm{C}$ was found in an Italian patient married to a Thai woman who also suffered from hepatitis B of genotype C.

\section{Discussion and Conclusions}

Italy, land of immigration, has become a multi-ethnic country with people coming from high and medium endemic disease areas in terms of HBV (5). Chronic hepatitis is one of the most widespread infections among immigrants, and it is mainly caused by $\operatorname{HBV}(13,14)$. According to the data that we collected, the number of foreign subjects (18) is basically equal to the number of the Italian ones (17) that we have analysed (Table 1). This shows, despite the limited number of samples (4), the significant presence of foreign people in our area. The exiguity of specimens led us to use in the processing only the frequency calculation. Among women (16), the majority (11, about $61 \%)$ were foreigners. This in accordance with the feminization process of migratory

Table 1. Subjects in whom the research of hepatitis B virus genotype has been performed from 2010 to 2014 : origin and gender.

\begin{tabular}{lcccccc} 
Nationality & Males (\%) & Males, \% of total & Females (\%) & Females, \% of total & Total & \% total \\
Italians & $12(70.59)$ & 63.1 & $5(29.41)$ & 31.25 & 17 & 48.6 \\
Foreigners & $7(38.9)$ & 36.9 & $11(61.1)$ & 68.75 & 18 & 51.4 \\
\hline Total & 19 & 100 & 16 & 100 & 35 & 100 \\
\hline
\end{tabular}

Table 2. Italian and foreign subjects on whom we performed the research of hepatitis B virus genotype from 2010 to 2014.

\begin{tabular}{|c|c|c|c|c|c|c|c|}
\hline HBV-DNA & & Italians & & & oreigner & & Total \\
\hline & M (\%) & $F(\%)$ & $\mathbf{M}+\mathrm{F}$ & M (\%) & F (\%) & $M+F$ & \\
\hline$\geq 10^{3}-\leq 10^{4} \mathrm{IU} / \mathrm{mL}$ & $2(18.2)$ & $2(18.2)$ & 4 & 0 & $7(63.6)$ & 7 & 11 \\
\hline$\geq 10^{4}-\leq 10^{5} \mathrm{IU} / \mathrm{mL}$ & 0 & 0 & 0 & $5(71.4)$ & $2(28.6)$ & 7 & 7 \\
\hline$\geq 10^{5}-\leq 10^{6} \mathrm{IU} / \mathrm{mL}$ & $3(75)$ & $1(25)$ & 4 & 0 & 0 & 0 & 4 \\
\hline$\geq 10^{6} \mathrm{IU} / \mathrm{mL}$ & $7(53.8)$ & $2(15.4)$ & 9 & $2(15.4)$ & $2(15.4)$ & 4 & 13 \\
\hline Total & $12(34.3)$ & $5(14.3)$ & 17 & $7(20)$ & $11(31.4)$ & 18 & 35 \\
\hline
\end{tabular}

M, male; F, female. 
Table 3. Italian and foreign subjects on whom we performed the research of hepatitis B virus genotype from 2010 to 2014 : nationality of origin and found genotypes.

\begin{tabular}{|c|c|c|c|c|c|c|c|c|c|c|c|c|c|c|c|c|}
\hline \multirow[t]{2}{*}{ Country } & \multicolumn{2}{|c|}{ Genotype A } & \multicolumn{2}{|c|}{ Genotype B } & \multicolumn{2}{|c|}{ Genotype C } & \multicolumn{2}{|c|}{ Genotype D } & \multicolumn{2}{|c|}{ Genotype E } & \multicolumn{2}{|c|}{ Genotype F } & \multicolumn{2}{|c|}{ Genotype G } & \multicolumn{2}{|c|}{ Total } \\
\hline & M & $\mathbf{F}$ & M & F & M & F & M & F & M & $\mathrm{F}$ & M & $\mathbf{F}$ & M & F & M & $\mathbf{F}$ \\
\hline Italy & 2 & - & - & - & 1 & - & 6 & 5 & - & - & 3 & - & - & - & 12 & 5 \\
\hline Romania & 2 & 2 & - & - & - & - & 1 & 2 & - & - & - & - & - & - & 3 & 4 \\
\hline China & - & - & - & 1 & - & - & - & - & - & - & - & - & - & - & - & 1 \\
\hline Poland & - & 1 & - & - & - & - & - & - & - & - & - & - & - & - & - & 1 \\
\hline Albania & - & - & - & - & - & - & 2 & 1 & - & - & - & - & - & - & 2 & 1 \\
\hline Thailand & - & - & - & - & - & 1 & - & - & - & - & - & - & - & - & - & 1 \\
\hline Bangladesh & - & - & - & - & 1 & - & - & - & - & - & - & - & - & - & 1 & - \\
\hline India & - & - & - & - & - & - & - & 1 & - & - & - & - & - & - & - & 1 \\
\hline Libya & - & - & - & - & - & - & 1 & - & - & - & - & - & - & - & 1 & - \\
\hline Philippines & - & - & - & 1 & - & - & - & - & - & - & - & - & - & - & - & 1 \\
\hline Moldova & - & - & - & - & - & - & - & 1 & - & - & - & - & - & - & - & 1 \\
\hline Total (\%) & $4(11.4$ & (8.57) & - & $2(5.71)$ & $2(5.71)$ & $1(2.86$ & $0(28.5$ & (28.57) & - & - & $3(8.57)$ & - & - & - & $19(54$ & $(45.7)$ \\
\hline
\end{tabular}

flows occurred in Europe and therefore in Italy, caused an increase in the female population (5).

We have analysed patients with virological infections, that is to say with HBV-DNA detectable in plasma. The specimens with HBV-DNA $\geq 10^{6}$ $\mathrm{IU} / \mathrm{mL}$ (15) values prevail and they belong for approximately $54 \%$ to Italian males, the biggest group, followed by specimens (11) with HBVDNA between $10^{3}$ and $10^{4} \mathrm{IU} / \mathrm{mL}$ where foreign females, as probably predictable, prevail, 7 (about 64\%) (Table 2). Of the foreign women analysed, 7 came from Eastern Europe: 4 from Romania, 1 from Poland, 1 from Moldova and 1 from Balkans, Albania (Table 3) (9). The remaining 4 female patients came respectively: 1 from Southern Asia (India), 1 from Eastern Asia (China) and 2 from South-EastAsia (Thailand and Philippines). The geographical distribution of HBV genotypes varies from region to region and the different genotypes do not have a regular distribution. The HBV genotype significantly affects the course of the illness: it is a variable that can influence its development both in terms of hepatic disease progression and of effectiveness of therapy $(4,6,7)$. In the Mediterranean areas genotype D prevails $(7,17)$.

The analysis of the HBV genotypes distribution allowed us to verify that in the area of the hospital of Terni, genotype D is not the only one existing, but it appears to be present also with other genotypes. Changes in the lifestyle, travels, and international trade can cause the spread among local population of different HBV genotypes. The global migration flow, which is more and more unrestrainable, could lead to a world-wide redistribution and change of genotypes in areas where previously they were not spread: important phenomenon to be monitored. The study of genotypes and of their distribution even in our region appear to be important, because it is correlated with clinical characteristics and with the virological response of HBV infection, in order to find an adequate and targeted therapy $(7,14)$.

\section{References}

1. Arankalle VA, Gandhe SS, Borkakoty BJ, et al. A novel HBV recombinant (genotype I) similar to Vietnam/Laos in a primitive tribe in eastern India. J Viral Hepat 2010;17:501-10.

2. Arauz-Ruiz P, Norder H, Robertson BH, Magnius LO. Genotype H: a new Amerindian genotype of hepatitis $\mathrm{B}$ virus revealed in Central America. J Gen Hepat 2002;83:2059-73.
3. Bassem SSG, Radwa OA, Hassan MEA. Hepatitis B virus genotyping: current methods and clinical implications. Int J Infect Dis 2010;14:941-53.

4. Binghui W, Yue F, Zheng L, et al. Distribution and diversity of hepatitis B virus genotypes in Yunnan, China. J Med Virol 2014;86:1675-82.

5. Cappuccini D, Grespi V, Proietti M, et al. HBV-DNA as marker of hepatitis $B$ virus infection in autochthonous and foreign population of the molecular biology laboratory of the immuno-haematology and blood transfusion unit, AO "S. Maria", Terni. Microbiol Med 2014;29:37-9.

6. Conti A, Pradella M. Le infezioni da virus epatotropi: la strategia diagnostica. RIMeL/ IJLaM, 2010;6:252-60.

7. Crobu MG, Ravanini P, Nicosia AM, et al. Distribuzione dei genotipi di HBV nell'area Novarese. Microbiol Med 2006;21.

8. Etsuro 0, Takafumi I, Hiroshi S, et al. Geographic distribution of hepatitis B virus (HBV) genotype in patients with chronic HBV infection in Japan. Hepatology 2001;34:590-4.

9. Europa.eu. Unione Europea. I paesi membri dell'Unione Europea. Available from: http//europa.eu/about-eu/countries/member-countries/index_it.htm

10. Fegato.com. Epatite B. Available from: http://www.fegato.com/ it/schede/malattie-e-condizioni/epatologia/detail_7473_epatiteb.aspx?c1 $=29$

11. Infomedics.it. Epatite B, una patologia globale. 240 milioni di portatori cronici dell'infezione. Available from: http:/www.infomedics.it

12. Mohammad RH, Mohsen A, Tahoora M. Hepatitis B genotypes in Iran. Mater Sociomed 2014;26:129-33.

13. Palumbo E, Scotto G, Cibelli DC, et al. Immigration and hepatitis B virus: epidemiological, clinical and therapeutic aspects. East Mediterr Health J 2008;14:784-90.

14. Palumbo E, Scotto G, Faleo G, et al. Prevalence of HBV genotypes in South American immigrants affected by HBV- related chronic active hepatitis. Brazil J Infect Dis 2007;11:311-3.

15. Ribeiro NR, Campos GS, Angelo AL, et al. Distribution of hepatitis $B$ virus genotypes among patients with chronic infection. Liver Int 2006;26:636-42.

16. Said AAB, Bui TS, Boris AR, et al. Molecular epidemiology and genotyping of hepatitis B virus of HBsAg-positive patients in Oman. Plos One 2014;9:e97759.

17. SEV Hep. Qual è l'effetto dei genotipi dell'HBV sul decorso naturale di un'infezione da HBV e sulla risposta alla terapia? Available from: http://viralhepatitis.ch/it/node/95 
18. Siemens. How can we improve patient care when managing infectious disease? Broad - Range diagnostic solutions for infectious disease management. Hepatitis B. Siemens Healthcare Diagnostics Inc, USA 2008.

19. Siemens. Trugene HBV genotyping assay. Trugene HBV modulo 2.0. Identificare il genotipo e svelare le mutazioni virali dell'Epatite B, Siemens Healthcare Diagnostics Inc, USA 2009.

20. Siemens. Trugene HBV, Genotyping Kit. For use with the OpenGene DNA Sequencing System. 28 tests.

21. Sumbul M. Hepatitis B virus genotypes: global distribution and clinical importance. World J Gastroenterol 2014;20:5427-34.
22. Tahoora M, Mohammad RH, Alireza R, et al. Hepatitis B virus genotypes distribution with HBsAg positive in the north of Iran (Mazandaran) during 2011-2014. Med Arch 2014;68:376-80.

23. Tatematsu K, Tanaka Y, Kurbanov F, et al. A genetic variant of hepatitis $\mathrm{B}$ virus divergent from known human and ape genotypes isolated from a Japanese patient and provisionally assigned to new genotype J. J Virol 2009;83:10538-47.

24. Yu H, Yuan Q, Ge SX, et al. Molecular and phylogenetic analyses suggest an additional hepatitis B virus genotype "I". PLoS One 2010;5:e9297. 